Article

\title{
Antitumor, Antiviral, and Anti-Inflammatory Efficacy of Essential Oils from Atractylodes macrocephala Koidz. Produced with Different Processing Methods
}

\author{
Sihao Gu ${ }^{1,+}{ }^{+}$Ling Li ${ }^{1, \dagger}{ }^{+}$Hai Huang ${ }^{2}$, Bing Wang $1,3, * \mathbb{C}$ and Tong Zhang ${ }^{1, *}$ \\ 1 School of Pharmacy, Experiment Center for Teaching and Learning, Shanghai University of Traditional \\ Chinese Medicine, 1200 Cai-lun Rd, Shanghai 201203, China \\ 2 Experimental Teaching Center of Pharmaceutical Sciences, School of Pharmacy, Fudan University, \\ 826 Zhang-heng Rd, Shanghai 201203, China \\ 3 Center for Pharmaceutics Research, Shanghai Institute of Materia Medica, Chinese Academy of Sciences, \\ 501 Hai-ke Rd, Shanghai 201203, China \\ * Correspondence: bwang@simm.ac.cn (B.W.); zhangtdmj@hotmail.com (T.Z.); Tel.: +86-021-51323068 (B.W.); \\ +86-021-51322318 (T.Z.); Fax: +86-021-51322315 (B.W. \& T.Z.) \\ + These authors contributed equally to this work. \\ Academic Editors: Valtcho Jeliazkov, Murray B Isman, Farid Chemat, Vassya Bankova and \\ Niko Radulović \\ check for \\ updates \\ Received: 20 July 2019; Accepted: 13 August 2019; Published: 15 August 2019

\begin{abstract}
Atractylodes macrocephala Koidz. has been used as an invigorating spleen drug for eliminating dampness and phlegm in China. According to recent researches, different processing methods may affect the drug efficacy, so we collected $A$. macrocephala from the Zhejiang Province, produced with different processing methods, crude A. macrocephala (CA) and bran-processed A. macrocephala (BA), then analyzed its essential oils (EOs) by GC/MS. The results showed 34 components representing $98.44 \%$ of the total EOs of CA were identified, and 46 components representing $98.02 \%$ of the total EOs of BA were identified. Atractylone is the main component in A. macrocephala. Compared with CA, BA has 46 detected compounds, 28 of which were identical, and 6 undetected compounds. Pharmacodynamic results revealed that the EOs of $\mathrm{CA}$ and atractylone exhibited more effective anticancer activity in HepG2, MCG803, and HCT-116 cells than the EOs of BA; while the EOs of BA exhibited simple antiviral effect on viruses H3N2, both the EOs and atractylone show anti-inflammatory activity by inhibiting the lipopolysaccharide (LPS)-induced nitric oxide (NO) production in ANA-1 cells.
\end{abstract}

Keywords: Atractylodes macrocephala Koidz.; essential oils; atractylone; processing methods; GC/MS; pharmacodynamic effect

\section{Introduction}

Atractylodes macrocephala Koidz. (Baizhu in Chinese), a perennial herb from the Compositae family, is a drug commonly used in traditional Chinese medicine. It has been used as a food and medicinal herb in China for thousand years [1]. In China, A. macrocephala is mainly distributed in Zhejiang Province which is known as one of authentic medicinal herbs "Zhebawei" [2]. Many components, such as essential oils (EOs), sesquiterpenoids, polysaccharides, amino acids, vitamins, resins, and other ingredients have been found in A. macrocephala up till recently [3,4]. A. macrocephala has many effects, such as strengthening the spleen, benefiting vital energy, eliminating dampness, hidroschesis, and soothing fetuses [5]. 
In China, the methods of Chinese medicine processing became more and more common after the Song Dynasty. The crude A. macrocephala (CA) and bran-processed A. macrocephala (BA) are the two drugs that are prepared in pieces which have been widely used as a tonic in China. Clinically, the CA is mainly used for spleen dampness and diuresis while after bran-processed, it can significantly relieve dryness and tonify Qi and spleen. It is because after processing, the content of EOs with sputum effect decreased, and the content of lactones which inhibited uterine contraction increased; hence the famous doctor Zhu Danxi in the Yuan Dynasty regarded BA as the miscarriage prevention medicine for the first time in the "Danxi Heart Law" [6]. The main components of A. macrocephala are EOs that are made up of atractylone, orange linoleum, elemene, and isoeugenol [7]. So after bran processing, what changes in the chemical composition of $A$. macrocephala have caused such changes in its pharmacological effects?

In recent years, the research on the active ingredients of $A$. macrocephala has been focused on its polysaccharides and lactones. The research on EOs of A. macrocephala focuses on component analysis, and rarely involved medicinal ingredients. Pharmacological studies and clinical practice have demonstrated that $A$. macrocephala possesses various bioactivities, including diarrhea, abdominal pain, and insufficiency of the stomach, intestine, liver, kidney, or insufficiency of the spleen with abundance of dampness [8,9]. A. macrocephala has a regulating effect on the gastrointestinal tract and is commonly used in the treatment of digestive tract diseases [9,10]. Atractylodes lactones have antitumor effects [11-13], but no study has been reported on whether the EOs of A. macrocephala has inhibitory effect on the digestive tract tumors; the previous research of the research group found that the EOs of Cinnamomi ramulus has antiviral and anti-inflammatory effects [14]. So, it suddenly occurred to us that since $A$. macrocephala extract has many pharmacological activities, and the EOs are one of the main active components of $A$. macrocephala, so the EOs of $A$. macrocephala might have antitumor, antiviral, and anti-inflammatory effects.

Here, we collected A. macrocephala from the Pan'an District, Jinhua City, Zhejiang Province, China and analyzed its EOs constituents by GC/MS. In addition, for further exploitation of this plant, the possible bioactivities of the EOs of CA and BA were examined, including antitumor, antiviral, and anti-inflammatory activities, to investigate the chemical compositions and biological activities of the EOs in the effective part, and find the material basis for its function. Here, our schematic illustration of the work is revealed in Figure 1.

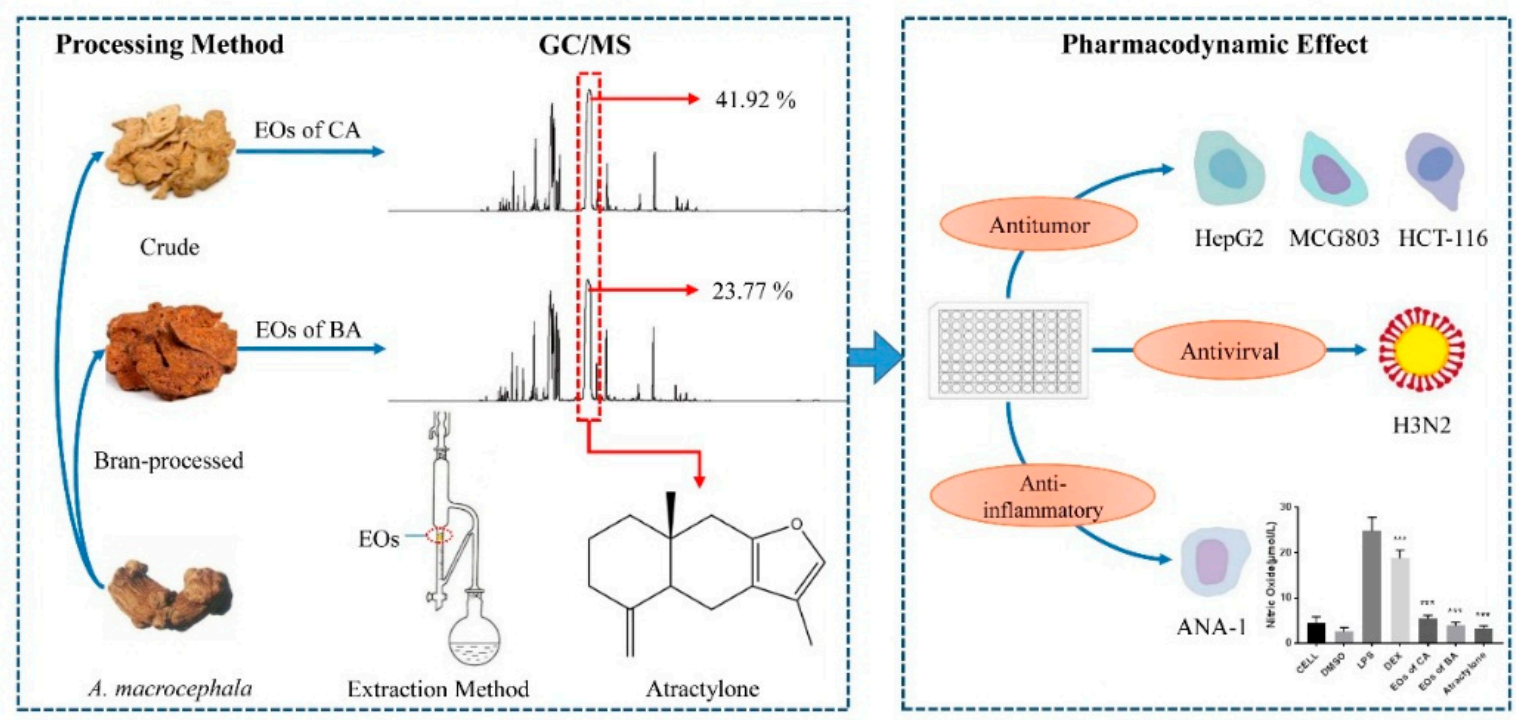

Figure 1. The relevance of chemical compositions in the EOs produced from A. macrocephala and biological activities. 


\section{Results}

\subsection{Chemical Composition of Essential Oils}

Hydrodistillation of CA yields 1.33\% $(v / w)$ and BA yields 1.07\% $(v / w)$ of the yellow EOs using the Chinese Pharmacopoeia appendix method (Part IV General rule 2202). We used the National Institute of Standards and Technology (NIST) database to match and select the material with the highest matching degree and reference to determine the compounds which are described in Figure 2 and Table 1 . A total of 34 components representing $98.44 \%$ of the total peak areas of CA were identified. The highest content component of the EOs of CA was atractylone (41.92\%). For BA, 46 components representing $98.02 \%$ of the total peak areas were identified and the highest content component of EOs of BA was atractylone (23.77\%). Compared with the EOs of CA, BA had 28 same compounds (84.98\% for the EOs of CA and $67.40 \%$ for the EOs of BA), 18 additional detected compounds, and 6 undetected compounds.

(A)

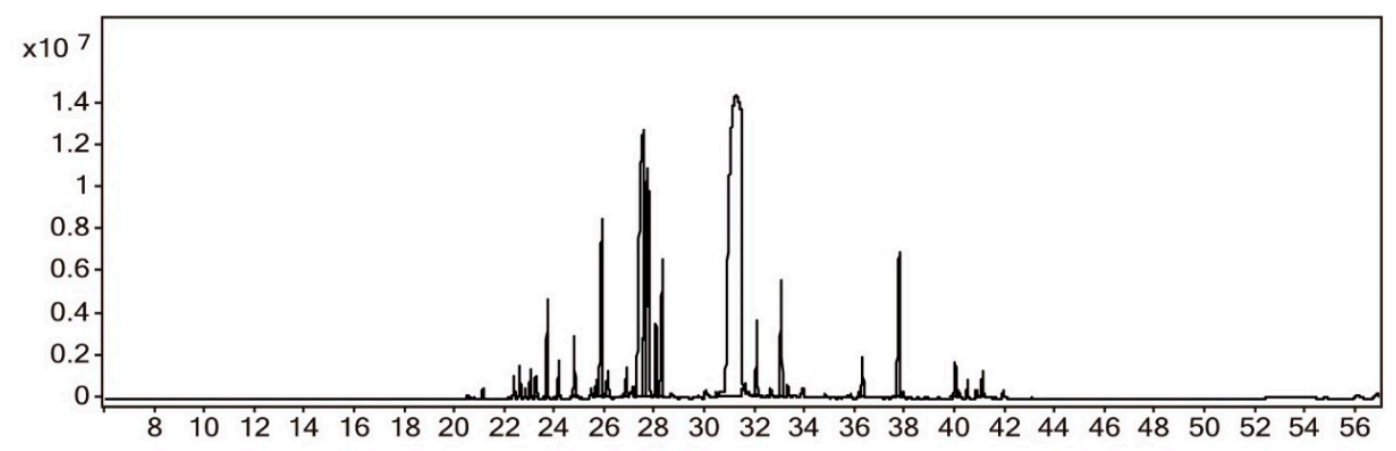

(B)

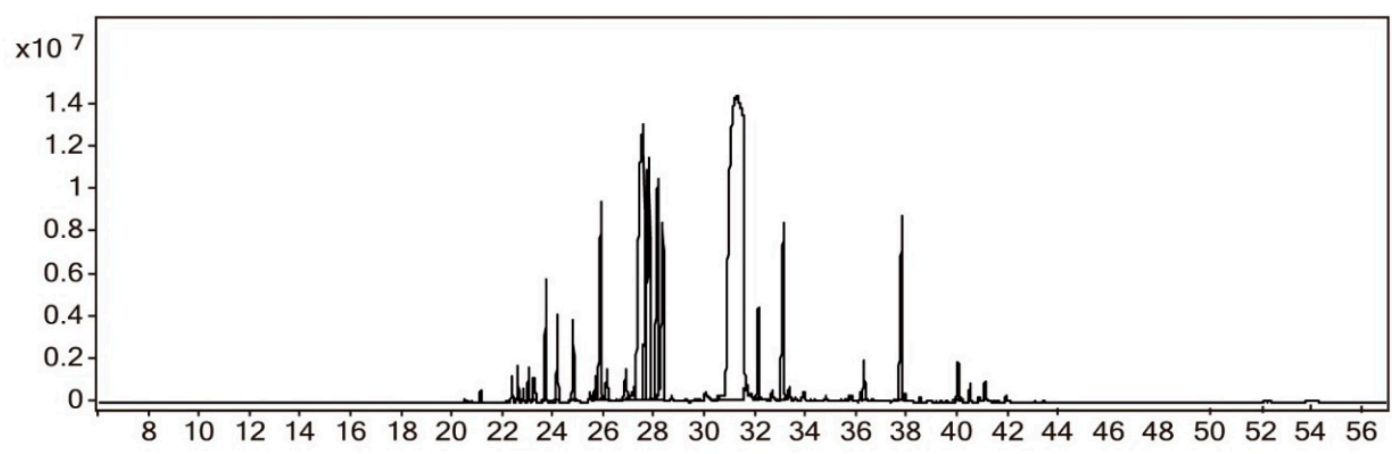

Figure 2. GC/MS chromatograms of the EOs of $A$. macrocephala. (A) GC/MS chromatograms of the EOs of crude A. macrocephala (CA); (B) GC/MS chromatograms of the EOs of bran-processed A. macrocephala (BA). 
Table 1. Chemical compositions and content * of the EOs of CA and BA.

\begin{tabular}{|c|c|c|c|c|c|c|c|c|c|}
\hline \multirow{2}{*}{ No. } & \multirow{2}{*}{$\begin{array}{l}\text { Retention } \\
\text { (min) }\end{array}$} & \multirow{2}{*}{ Compounds } & \multirow{2}{*}{$\begin{array}{l}\text { Molecular } \\
\text { Formula }\end{array}$} & \multicolumn{2}{|c|}{ EOs of CA } & \multicolumn{2}{|c|}{ EOs of BA } & \multirow{2}{*}{ CAS No. } & \multirow{2}{*}{ Reference } \\
\hline & & & & Area $(\%)$ & Similarity & Area $(\%)$ & Similarity & & \\
\hline 1 & 21.085 & $\alpha$-Guaiene & $\mathrm{C}_{15} \mathrm{H}_{24}$ & ND & & 0.13 & 87.5 & $3691-12-1$ & [15] \\
\hline 2 & 22.327 & $\alpha$-Amylcinnamyl alcohol & $\mathrm{C}_{14} \mathrm{H}_{20} \mathrm{O}$ & 0.35 & 87.8 & 0.29 & 87.9 & $101-85-9$ & [16] \\
\hline 3 & 22.561 & Berkheyaradulene & $\mathrm{C}_{15} \mathrm{H}_{24}$ & 0.54 & 87.8 & 0.42 & 87.7 & $65372-78-3$ & [17] \\
\hline 4 & 22.769 & Eremophylene & $\mathrm{C}_{15} \mathrm{H}_{24}$ & ND & & 0.15 & 83.7 & $10219-75-7$ & [18] \\
\hline 5 & 22.987 & $\alpha$-Gurjunene & $\mathrm{C}_{15} \mathrm{H}_{24}$ & 0.48 & 93.1 & 0.97 & 92.8 & $489-40-7$ & [19] \\
\hline 6 & 23.189 & $\beta$-Isocomene & $\mathrm{C}_{15} \mathrm{H}_{24}$ & ND & & 0.26 & 71.1 & $74311-15-2$ & [17] \\
\hline 7 & 23.236 & (-)- $\beta$-Caryophyllene & $\mathrm{C}_{15} \mathrm{H}_{24}$ & ND & & 0.28 & 70 & $87-44-5$ & [20] \\
\hline 8 & 23.674 & Isoledene & $\mathrm{C}_{15} \mathrm{H}_{24}$ & 1.85 & 96.3 & 1.75 & 96.3 & $95910-36-4$ & [7] \\
\hline 9 & 24.135 & $\gamma$-Elemene & $\mathrm{C}_{15} \mathrm{H}_{24}$ & 0.64 & 93.5 & 1.14 & 93.7 & 29873-99-2 & [21] \\
\hline 10 & 24.753 & $\alpha$-Caryophyllene & $\mathrm{C}_{15} \mathrm{H}_{24}$ & 1.21 & 92.5 & 1.07 & 92.5 & $6753-98-6$ & [22] \\
\hline 11 & 25.622 & $\begin{array}{l}\text { 1,2,3,4,4a,7-Hexahydro-1,6-dimethyl-4- } \\
\text { (1-methylethyl)naphthalene }\end{array}$ & $\mathrm{C}_{15} \mathrm{H}_{24}$ & 0.33 & 81.1 & 0.34 & 83.2 & $16728-99-7$ & {$[23]$} \\
\hline 12 & 25.850 & Cedrol & $\mathrm{C}_{15} \mathrm{H}_{26} \mathrm{O}$ & ND & & 0.14 & 51.6 & $77-53-2$ & [24] \\
\hline 13 & 25.864 & $\beta$-Selinene & $\mathrm{C}_{15} \mathrm{H}_{24}$ & 4.88 & 95.4 & 4.36 & 95.3 & $17066-67-0$ & [25] \\
\hline 14 & 26.085 & trans-Nuciferol & $\mathrm{C}_{15} \mathrm{H}_{22} \mathrm{O}$ & 0.69 & 76 & 0.67 & 78.6 & 39599-18-3 & [26] \\
\hline 15 & 26.829 & Calarene & $\mathrm{C}_{15} \mathrm{H}_{24}$ & 0.84 & 91.5 & 0.74 & 91.7 & $17334-55-3$ & [27] \\
\hline 16 & 27.136 & Zingiberene & $\mathrm{C}_{15} \mathrm{H}_{24}$ & 0.33 & 76.1 & 0.25 & 65.8 & $495-60-3$ & [28] \\
\hline 17 & 27.441 & (-)-Norbornenone & $\mathrm{C}_{7} \mathrm{H}_{8} \mathrm{O}$ & 1.06 & 57.5 & ND & & $16620-79-4$ & [29] \\
\hline 18 & 27.459 & 1,2,3,6-Tetramethylbicyclo[2.2.2] octa-2,5-diene & $\mathrm{C}_{12} \mathrm{H}_{18}$ & 1.68 & 58.5 & ND & & $62338-43-6$ & [30] \\
\hline 19 & 27.486 & 2-Methoxy-4-methyl-1-(1-methylethyl)benzene & $\mathrm{C}_{11} \mathrm{H}_{16} \mathrm{O}$ & ND & & 0.55 & 60.9 & $1076-56-8$ & [30] \\
\hline 20 & 27.486 & 3,7-Guaiadiene & $\mathrm{C}_{15} \mathrm{H}_{24}$ & 9.57 & 75.7 & ND & & $6754-04-7$ & [31] \\
\hline 21 & 27.497 & Eudesma-4(14),11-diene & $\mathrm{C}_{15} \mathrm{H}_{24}$ & 5.34 & 72.6 & 5.38 & 70.2 & $17066-67-0$ & [30] \\
\hline 22 & 27.500 & 1-Heptanal & $\mathrm{C}_{7} \mathrm{H}_{14} \mathrm{O}$ & ND & & 1.74 & 57.9 & 111-71-7 & [24] \\
\hline 23 & 27.507 & 1-Adamantylethanol & $\mathrm{C}_{12} \mathrm{H}_{20} \mathrm{O}$ & ND & & 3.66 & 61.4 & $6240-11-5$ & [32] \\
\hline 24 & 27.519 & 2-Phenylacetamide & $\mathrm{C}_{8} \mathrm{H}_{9} \mathrm{NO}$ & ND & & 6.32 & 64.3 & 103-81-1 & [33] \\
\hline 25 & 27.674 & Eudesma-3,7(11)-diene & $\mathrm{C}_{15} \mathrm{H}_{24}$ & 5.57 & 80.6 & 4.36 & 79.6 & $6813-21-4$ & [34] \\
\hline 26 & 27.708 & Caryophyllene & $\mathrm{C}_{15} \mathrm{H}_{24}$ & 0.57 & 61.9 & ND & & $87-44-5$ & [30] \\
\hline 27 & 27.721 & $\beta$-Himachalene & $\mathrm{C}_{15} \mathrm{H}_{24}$ & ND & & 0.19 & 61.4 & $1461-03-6$ & [30] \\
\hline 28 & 27.723 & Isolongifolene & $\mathrm{C}_{15} \mathrm{H}_{24}$ & 4.33 & 81.3 & 3.04 & 75.9 & $1135-66-6$ & [35] \\
\hline 29 & 27.732 & $\beta$-Eudesmol & $\mathrm{C}_{15} \mathrm{H}_{26} \mathrm{O}$ & ND & & 0.77 & 54.3 & $473-15-4$ & [36] \\
\hline 30 & 27.738 & trans-2-Heptenal & $\mathrm{C}_{7} \mathrm{H}_{12} \mathrm{O}$ & ND & & 0.21 & 61.8 & $18829-55-5$ & [37] \\
\hline 31 & 27.756 & (9E,12E)-9,12-Octadecadienoic acid methylester & $\mathrm{C}_{19} \mathrm{H}_{34} \mathrm{O}_{2}$ & ND & & 0.41 & 76.8 & $2566-97-4$ & [24] \\
\hline 32 & 28.089 & $\gamma$-Gurjunene & $\mathrm{C}_{15} \mathrm{H}_{24}$ & 1.31 & 95 & 4.37 & 94.6 & $22567-17-5$ & [38] \\
\hline 33 & 28.297 & Aromadendrene & $\mathrm{C}_{15} \mathrm{H}_{24}$ & 3.23 & 91.1 & 3.29 & 91.9 & $489-39-4$ & [7] \\
\hline 34 & 29.978 & $\beta$-Vatirenene & $\mathrm{C}_{15} \mathrm{H}_{22}$ & 0.37 & 78.5 & 0.35 & 77.4 & $27840-40-0$ & [7] \\
\hline 35 & 31.173 & Atractylone & $\mathrm{C}_{15} \mathrm{H}_{20} \mathrm{O}$ & 41.92 & 95 & 23.77 & 95 & $6989-21-5$ & [39] \\
\hline
\end{tabular}


Table 1. Cont.

\begin{tabular}{|c|c|c|c|c|c|c|c|c|c|}
\hline \multirow{2}{*}{ No. } & \multirow{2}{*}{$\begin{array}{l}\text { Retention } \\
\text { (min) }\end{array}$} & \multirow{2}{*}{ Compounds } & \multirow{2}{*}{$\begin{array}{l}\text { Molecular } \\
\text { Formula }\end{array}$} & \multicolumn{2}{|c|}{ EOs of CA } & \multicolumn{2}{|c|}{ EOs of BA } & \multirow{2}{*}{ CAS No. } & \multirow{2}{*}{ Reference } \\
\hline & & & & Area (\%) & Similarity & Area (\%) & Similarity & & \\
\hline 36 & 31.239 & (Z)-3-decen-1-ol & $\mathrm{C}_{10} \mathrm{H}_{20} \mathrm{O}$ & ND & & 8.99 & 78.2 & $10340-22-4$ & [30] \\
\hline 37 & 31.514 & Agarospirol & $\mathrm{C}_{15} \mathrm{H}_{26} \mathrm{O}$ & ND & & 6.25 & 77.9 & $1460-73-7$ & [40] \\
\hline 38 & 31.559 & $\beta$-Elemene & $\mathrm{C}_{15} \mathrm{H}_{24}$ & 0.25 & 79 & ND & & $515-13-9$ & [41] \\
\hline 39 & 31.616 & $\begin{array}{l}\text { 4,11,11-Trimethyl-8-methylenebicyclo[7.2.0] } \\
\text { undec-4-ene }\end{array}$ & $\mathrm{C}_{15} \mathrm{H}_{24}$ & ND & & 0.16 & 80.3 & $13877-93-5$ & [42] \\
\hline 40 & 32.066 & 10S,11S-Himachala-3(12),4-diene & $\mathrm{C}_{15} \mathrm{H}_{24}$ & 1.54 & 94.3 & 1.38 & 94.4 & $60909-28-6$ & [43] \\
\hline 41 & 32.611 & Dehydroaromadendrene & $\mathrm{C}_{15} \mathrm{H}_{22}$ & 0.29 & 81.5 & 0.24 & 83.1 & 698388-95-3 & [30] \\
\hline 42 & 33.039 & 4,5-Dehydroisolongifolene & $\mathrm{C}_{15} \mathrm{H}_{22}$ & ND & & 0.45 & 79.5 & $1246777-02-5$ & [36] \\
\hline 43 & 33.072 & Aristolone & $\mathrm{C}_{15} \mathrm{H}_{22} \mathrm{O}$ & 2.69 & 87.1 & 3.58 & 82.7 & $6831-17-0$ & [44] \\
\hline 44 & 33.283 & 3,7,11-Trimethyl-dodeca-2,4,6,10-tetraenal & $\mathrm{C}_{15} \mathrm{H}_{22} \mathrm{O}$ & 0.34 & 78.2 & 0.28 & 81.2 & $13832-89-8$ & [45] \\
\hline 45 & 33.865 & Spathulenol & $\mathrm{C}_{15} \mathrm{H}_{24} \mathrm{O}$ & 0.34 & 76.7 & ND & & $6750-60-3$ & [7] \\
\hline 46 & 33.874 & $\begin{array}{l}\text { 3,4,7,8-Tetrahydro-8,8,9,9-tetramethyl-2H-2, } \\
\text { 4a-methanonaphthalene }\end{array}$ & $\mathrm{C}_{15} \mathrm{H}_{22}$ & $\mathrm{ND}$ & & 0.25 & 77.9 & $67517-14-0$ & {$[46]$} \\
\hline 47 & 36.250 & Velleral & $\mathrm{C}_{15} \mathrm{H}_{20} \mathrm{O}_{2}$ & 1.02 & 85.3 & 0.70 & 84.2 & $50656-61-6$ & [47] \\
\hline 48 & 37.741 & $\alpha$-Curcumene & $\mathrm{C}_{15} \mathrm{H}_{22}$ & 3.65 & 89.2 & 3.95 & 88.8 & $644-30-4$ & {$[7]$} \\
\hline 49 & 39.958 & Procerin & $\mathrm{C}_{15} \mathrm{H}_{18} \mathrm{O}_{2}$ & 0.83 & 72.3 & 0.67 & 74.2 & $552-96-5$ & [48] \\
\hline 50 & 40.439 & 8,9-dehydro-9-formyl-Cycloisolongifolene & $\mathrm{C}_{16} \mathrm{H}_{22} \mathrm{O}$ & 0.31 & 69 & 0.25 & 68.8 & $1206188-76-2$ & [7] \\
\hline 51 & 41.022 & $\begin{array}{l}\text { 3a,5,6,7,8,8a,9,9a-Octahydro-5,8a-dimethyl-3- } \\
\text { methylenenaphtho[2-b]furan-2(3H)-one } \\
\text { 1,2,3,3a,4,5-Hexahydro-1,1,4,4-tetramethyl-2, }\end{array}$ & $\mathrm{C}_{15} \mathrm{H}_{20} \mathrm{O}_{2}$ & 0.72 & 89.8 & 0.36 & 89.4 & $80367-94-8$ & {$[48]$} \\
\hline 52 & 41.861 & $\begin{array}{c}\text { 3b-methano-3bH-cyclopenta[1,3]cyclopropa } \\
{[1,2] \text { benzene-6-carboxaldehyde }}\end{array}$ & $\mathrm{C}_{16} \mathrm{H}_{22} \mathrm{O}$ & 0.23 & 68.7 & 0.13 & 67.9 & $59820-24-5$ & [48] \\
\hline Total & & & & 98.44 & & 98.02 & & & \\
\hline
\end{tabular}

${ }^{*} \mathrm{ND}=$ Not Detected 


\subsection{Antitumor Activity of Essential Oil from A. macrocephala}

According to the results of in vitro cytotoxicity experiments, SPSS statistical software was used to treat the cell proliferation inhibition rate data, and $\mathrm{IC}_{50}$ values of HepG2, MCG803, and HCT-116 cells were inhibited by atractylone, the EOs of CA, and the EOs of BA. As shown in Figure 3, the atractylone inhibited the proliferation of HepG2 and HCT-116 cells with lower $\mathrm{IC}_{50}$ values than the EOs of CA and the EOs of BA; the EOs of CA inhibited the proliferation of HepG2 cells with lower $\mathrm{IC}_{50}$ values than the EOs of BA. It is speculated that atractylone has strong antitumor activity in HepG2 and HCT-116 cells, and EOs of BA show weaker antitumor effect than the EOs of CA.

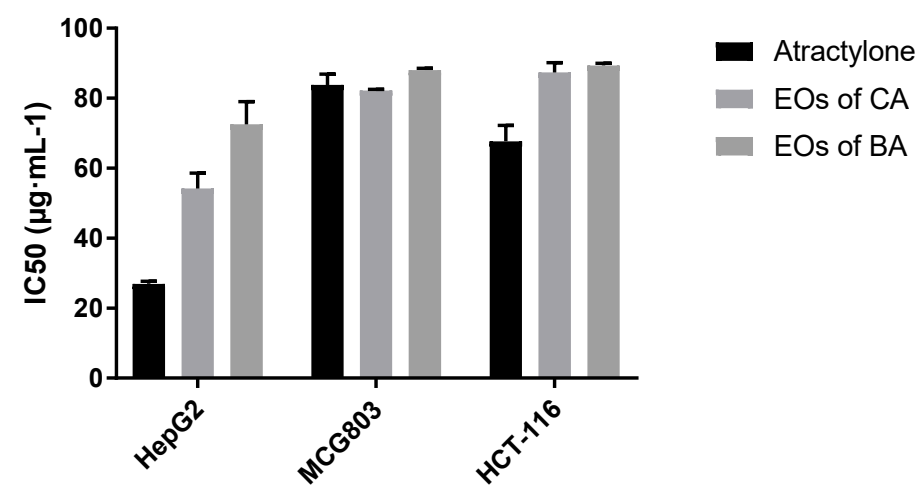

Figure 3. Inhibition of proliferation of HepG2, MCG803, and HCT-116 cells by atractylone, the EOs of $\mathrm{CA}$ and the EOs of BA $(n=3)$.

\subsection{Antiviral Activity of Essential Oil from A. macrocephala}

In order to confirm the possible activity of A. macrocephala for antiviral activity in traditional Chinese medicine, the EOs were evaluated for its cytotoxicity and inhibition against the influenza virus $\mathrm{H} 3 \mathrm{~N} 2$ in vitro by complete cytopathic effect (CPE) inhibition rate assay, with ribavirin as the positive control. Ribavirin had good virucidal activity with $\mathrm{TC}_{50}$ value of $14.72 \mu \mathrm{g} \cdot \mathrm{mL}^{-1}$ and no cytotoxicity at $25 \mu \mathrm{g} \cdot \mathrm{mL}^{-1}$. The $\mathrm{IC}_{50}$ of atractylone, the EOs of CA and BA were all unmeasurable, but CPE inhibition H3N2 rates of EOs of CA were $25 \%$ at the concentration of $6.25 \mu \mathrm{g} \cdot \mathrm{mL}^{-1}$, suggesting that it can partially inhibit the production of $\mathrm{CPE}$ of $\mathrm{H} 3 \mathrm{~N} 2$ influenza virus; the inhibition rate is $<50 \%$, suggesting that its anti-H3N2 influenza virus has limited effect. The atractylone and the EOs of BA showed no effects on the H3N2 influenza virus.

\subsection{Anti-Inflammatory Activity of EOs from A. macrocephala}

The inhibitors of NO production in macrophages via lipopolysaccharide (LPS) stimulation are considered as anti-inflammatory agents. We first investigated different concentrations of EOs of CA, EOs of BA and atractylone on the viability of ANA-1 cells by the thiazolyl blue tetrazolium bromide (MTT) method. As shown in Figure 4A, the administration of EOs of CA, EOs of BA and atractylone at $50 \mu \mathrm{g} \cdot \mathrm{mL}^{-1}$ does not affect the cell activity state.

Then we investigated the NO inhibitory effects of different concentrations of LPS, dexamethasone (DEX), EOs of CA, EOs of BA and atractylone on lipopolysaccharide (LPS)-activated ANA-1 cells. As shown in Figure 4B, DMSO at the concentrations of 1:2500 has an inhibitory effect on NO secreted by cells. Compared with the normal group, the cells secreted a large amount of NO after LPS stimulation, and the content of NO secreted by the positive drug DEX decreased significantly. The DEX, EOs of CA, EOs of $\mathrm{BA}$, and atractylone can significantly reduce the secretion of the NO content after stimulation. Therefore, it is believed that the EOs of CA, EOs of BA, and atractylone have anti-inflammatory activity. 
(A)

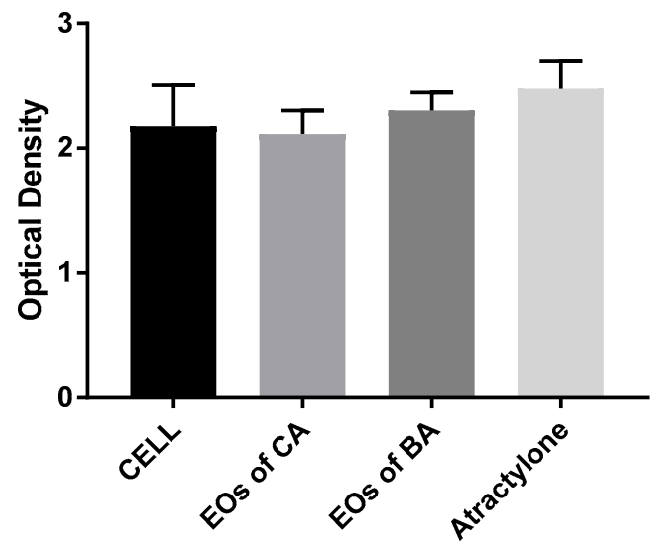

(B)

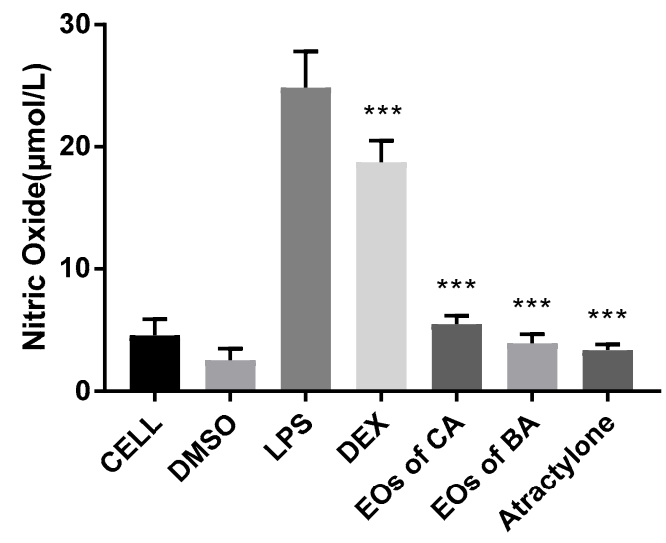

Figure 4. (A) Effects of EOs of CA, EOs of BA, and atractylone on the viability of ANA-1 cells $(n=3)$. cell: blank control; cell + EOs of CA, EOs of BA and atractylone: $\mathrm{EO}$ of $\mathrm{CA}$, EOs of $\mathrm{BA}$ and atractylone at $50 \mu \mathrm{g} \cdot \mathrm{mL}^{-1}$ respectively. (B) NO inhibitory effects of EOs of CA, EOs of BA and atractylone on LPS-activated ANA-1 cells $(n=3)$. cell: blank control; DMSO: DMSO at the concentrations of 1:2500; LPS: LPS control; DEX: positive control of DEX at $10 \mu \mathrm{g} \cdot \mathrm{mL}^{-1}$; EOs of CA, EOs of BA and atractylone: EOs of $\mathrm{CA}$, EOs of BA and atractylone at $50 \mu \mathrm{g} \cdot \mathrm{mL}^{-1}$ respectively; ${ }^{* * *}: p<0.001 \mathrm{vs}$. LPS.

\section{Discussion}

A. macrocephala Koidz. produced with two different processing methods, CA and BA, are commonly used in Chinese herbal medicine pieces. Previous literature studies have shown that frying with bran can reduce the dryness of the drug and improve its spleen tonifying activity [49]. EOs are plant-derived aromatic compounds that have a wide range of biological activities, but they act slowly, and they are usually unstable under light or heat, difficult to extract, and so on [50]. Based on this, we used GC/MS to study the EOs components of CA and BA. We found that the dryness nature may be related to the content of EOs, and also to the addition, no detection, or conversion of other compounds. The postoperative abortion may be related to 2-Phenylacetamide $(6.32 \%)$, which has estrogenic activities [51] according to reports of $A$. macrocephala after bran-processed and does not exist in the EOs of CA.

The results of antitumor activity studies showed that the EOs of CA showed better activity in gastric cancer, intestinal cancer, and liver cancer cells. We studied the EOs components of CA and BA, and found that $\beta$-elemene and 3,7-guaiadiene are unique ingredients of the EOs of CA. $\beta$-elemene reduced cell viability and induced apoptosis in HCT116 and HT29 cells and caused cell cycle arrest at the G2 phase and induced apoptosis of SGC-7901 cells through a mitochondrial-dependent apoptotic pathway [52,53]. The EOs in Phoebe hui Cheng ex Yang exhibited significant antitumor properties, with 3,7-guaiadiene as the main constituent in the EOs [54], the content of 3,7-guaiadiene in the EOs of CA is $9.57 \%$. So we can speculate that the antitumor activity of the EOs of CA is better than that of the EOs of BA, and the experimental results showed the same conclusion.

Anti-inflammatory experiments showed that EOs of BA has better activity. Some scholars have found that the chemical composition of EOs extracted from Brazilian propolis exhibited antibacterial activity, with $\gamma$-elemene as the main component [55]. The EOs isolated by the microwave-ultrasonic apparatus from Teucrium pruinosum leaves which contains agarospirol, the most abundant component $(45.53 \%)$, can be a suitable candidate for use as a novel anticancer, anti-inflammatory, and antioxidant medication [56]; the content of agarospirol is $6.25 \%$ in the EOs of BA. Therefore, we believe that the anti-inflammatory ability of the EOs of BA may be stronger than that of the EOs of CA, and the experimental conclusion is reasonable. 
Atractylone, the main compound in both EOs of CA and BA, can reduce allergic rhinitis (AR) clinical symptoms and biomarkers including rub scores, total IgE, histamine, prostaglandin D2, thymic stromal lymphopoietin, interleukin (IL)-1 $\beta$, IL-4, IL-5, IL-6, IL-13, tumor necrosis factor- $\alpha$, cyclooxygenase-2, intercellular adhesion molecule-1, and macrophage inflammatory protein-2, which suggested that atractylone is a potential therapeutic agent for AR, so atractylone has a good immune and anti-inflammatory activity [57].

$\mathrm{NO}$ as a free radical in the body, is associated with the occurrence of various intestinal diseases such as intestinal inflammation and increased intestinal mucosal permeability [58]. Literature research shows that reduction of tight proteins such as claudins (Cldn), Zona occludin-1 (ZO1), and occludin (Ocln) can cause inflammatory bowel disease (IBD) [58-60]. The experimental results of this study showed that the EOs of $A$. macrocephala and atractylone can significantly reduce the NO content secreted by LPS after ANA-1 cells stimulation, and have good anti-inflammatory activity, but little research has been done on its anti-inflammatory mechanism. It is believed that $A$. macrocephala is a spleen-requiring herb in Chinese medicine. These results revealed that the EOs of $A$. macrocephala has a good inhibitory effect on the gastrointestinal tumor cells. Based on this, we intend to design a follow-up experiment to explore the anti-inflammatory effect of the EOs on gastrointestinal inflammation and its anti-inflammatory mechanism. The preliminary results showed that atractylone reduces the intestinal inflammatory response, suggesting that its anti-inflammatory mechanism may be related to $\mathrm{Cldn}, \mathrm{ZO} 1$, and Ocln in cells, and the specific anti-inflammatory mechanism needs further experimental verification.

\section{Materials and Methods}

\subsection{Plant Materialsand Chemicals}

A. macrocephala Koidz. were purchased from Pan'an District, Jinhua City, Zhejiang Province at the beginning of 2019, and were identified by Jun-Song Li, the senior experimenter of Teaching and Experimental Center of Shanghai University of Traditional Chinese Medicine. Preparation of crude A. macrocephala: After harvesting fresh medicinal herbs, wash, evenly slice, and dry at room temperature. Preparation of bran-processed A. macrocephala: The crude A. macrocephala were prepared according to the 2015 edition of the Pharmacopoeia of the People's Republic of China. According to the ratio of crude $A$. macrocephala: sprinkle the candied bran $(10: 1, \mathrm{~g} / \mathrm{g})$ into a hot pot, add the crude A. macrocephala when it is smoked, fry until yellow brown, and escape the aroma, remove, sieve to remove the bran.

MDCK, ANA-1, and influenza viruses H3N2 was kindly provided by Teaching Center of Pharmaceutical Sciences, School of Pharmacy, Fudan University (Shanghai, China). HepG2, MCG803, and HCT-116 cells were provided by Dalian Mei-lun Biotechnology Co., Ltd. (Liaoning, China).

Atractylone (HPLC $\geq 95 \%$ ) was purchased from Shanghai Xi-Jian Biological Technology Co., Ltd. (Shanghai, China); Ethyl acetate (Analytical Reagent) was purchased from Sinopharm Chemical Reagent Co., Ltd. (Shanghai, China); Fetal bovine serum (FBS), dulbecco's modified eagle medium (DMEM), DMSO, LPS, DEX, Cell Counting Kit-8 (CCK-8) and MTT was purchased from Sigma-aldrich Chemical Reagent Co., Ltd. (Shanghai, China).

\subsection{Extraction Methods}

The crude and bran-processed A. macrocephala were smashed through the No. 2 sieve, weighed $100 \mathrm{~g}$, placed in a $1000 \mathrm{~mL}$ round bottom flask, and $500 \mathrm{~mL}$ of water and several glass beads were added. After shaking and mixing well, they were connected with the essential oil tester and the reflux condenser, filled the water at the upper end of the condensation tube till the graduated portion of the essential oil tester and overflowed into the flask. The electric jacket was heated slowly to boiling and was kept for about $5 \mathrm{~h}$ until the amount of oil in the measuring device no longer increased; then stop heating, put it for a while, open the piston at the lower end of the measuring device, slowly release the water to the upper end of the oil layer up to $5 \mathrm{~mm}$ above the 0 line. Leave it for more than $1 \mathrm{~h}$, then 
turn on the piston to lower the oil layer until its upper end was flush with the scale 0 line, read the volatile oil amount, and calculate the content $(\%, v / w)$ of the volatile oil in the test sample.

\subsection{Chemical Components Analysis by GC/MS}

GC/MS analysis of the test solution was performed on a gas chromatograph (HP-7890, Agilent Technologies, Santa Clara, CA, USA) coupled with a mass selective detector (HP-5977, Agilent Technologies) equipped with an HP-5MS fused silica column $(30 \mathrm{~m} \times 0.25 \mathrm{~mm}, 0.25 \mu \mathrm{m})$. The oven temperature was kept at $60^{\circ} \mathrm{C}$ for $5 \mathrm{~min}$, then warmed to $250{ }^{\circ} \mathrm{C}$ at $4{ }^{\circ} \mathrm{C} / \mathrm{min}$ and held at this temperature for $5 \mathrm{~min}$. A splitless injection was performed with helium gas at a flow rate of $0.9 \mathrm{~mL} / \mathrm{min}$ as the carrier gas. The spectrometer uses an electronic shock (EI) mode with a scan range of 40 to $400 \mathrm{~m} / \mathrm{z}$, an ionization energy of $70 \mathrm{eV}$, and a scan rate of $0.2 \mathrm{~s}$. The transmission line temperature and ion source temperature were $280^{\circ} \mathrm{C}$ and $230^{\circ} \mathrm{C}$, respectively [30]. For analysis purpose, EOs of CA, EOs of BA and atractylone were dissolved in ethyl acetate.

\subsection{Effects on Liver Cancer, Gastric Cancer, and Intestinal Cancer Cells}

Logarithmic growth phase cells were seeded in 96-well culture plates at a cell number of $1 \times 10^{4}$ cells $\mathrm{mL}^{-1}$. After the cell density reached $75 \%$, different concentrations of EOs were added and allowed to act for $24 \mathrm{~h}$. Then add CCK- 8 to each well, react at $37^{\circ} \mathrm{C}$ for $24 \mathrm{~h}$, discard the supernatant and add $100 \mu \mathrm{L}$ of DMSO per well, shake well, and measure the optical density OD of each well at $450 \mathrm{~nm}$.

\subsection{Anti-H3N2 Virucidal Activity}

\subsubsection{Sample Cytotoxicity Test}

MDCK cells were seeded onto 96-well culture plates and cultured for $24 \mathrm{~h}$. After forming cell monolayers, different concentrations of sample dilutions were added. After $72 \mathrm{~h}$ of incubation, cell morphology changes were observed under microscope and cell viability was determined by MTT assay.

\subsubsection{In vitro Antiviral Virus Test}

MDCK cells were seeded onto 96-well culture plates and cultured for $24 \mathrm{~h}$ to form a cell monolayer. The cells were infected with influenza virus solution for $2 \mathrm{~h}$, and then replaced with the maximum non-toxic concentration (concentration of cell activity $\geq 90 \%$ ). After the sample was diluted for $72 \mathrm{~h}$, the CPE was observed under a microscope to determine the inhibitory effect of the sample on influenza virus.

\subsection{Anti-Inflammatory Activity}

\subsubsection{MTT Method to Investigate the Effect of Test Drugs on Cell Viability}

A single cell suspension was prepared, $1000 \mathrm{rpm}$ for $5 \mathrm{~min}$, and the supernatant was discarded. The cells were resuspended in $1 \mathrm{~mL}$ of $10 \%$ FBS medium, counted with the gentian violet [61], and the cell concentration was adjusted to $2 \times 10^{6}$ cells $\cdot \mathrm{mL}^{-1}$; evenly inoculate the cells in a 96-well cell culture plate, add $100 \mu \mathrm{L}$ of the cell suspension to each well, and incubate for $24 \mathrm{~h}$ at $37^{\circ} \mathrm{C}$ in a $5 \% \mathrm{CO}_{2}$ saturated humidity incubator. After incubation, the cells were infected with different concentrations of EOs of CA, EOs of BA and atractylone $\left(50 \mu \mathrm{g} \cdot \mathrm{mL}^{-1}\right)$. After co-culture for $24 \mathrm{~h}$, add $50 \mu \mathrm{L}$ of MTT solution at $5 \mathrm{mg} \cdot \mathrm{mL}^{-1}$ to each well, shake well, continue to culture for $4 \mathrm{~h}$, carefully aspirate the supernatant, add $200 \mu \mathrm{L}$ of DMSO, shake well, and measure the absorbance of each well at $570 \mathrm{~nm}$. 


\subsubsection{Inhibition of ANA-1 Cell Inflammatory Model Induced by LPS Stimulation}

NO production was assessed indirectly by the quantification of nitrite and nitrate according to the Griess reaction [62,63]. DEX was selected as a positive control [64]. Each tested sample was dissolved in DMSO, and diluted with fresh FBS-free DMEM media to final concentration with DMSO (1:2500). The ANA-1 macrophages were seeded in 96-well plates $\left(2 \times 10^{6}\right.$ cells $\left.\cdot \mathrm{mL}^{-1}\right)$ and co-incubated with samples EOs of CA, EOs of BA and atractylone $\left(50 \mu \mathrm{g} \cdot \mathrm{mL}^{-1}\right)$ and LPS $\left(0.25 \mu \mathrm{g} \cdot \mathrm{mL}^{-1}\right)$. After incubation at $37^{\circ} \mathrm{C}$ for $24 \mathrm{~h}$, the culture supernatant was mixed with $50 \mu \mathrm{L}$ Griess Reagent to determine the NO production. Absorbance was measured at $570 \mathrm{~nm}$ using a microtiter plate reader.

\section{Conclusions}

The EOs of BA can partially inhibit the production of CPE of H3N2 influenza virus; the order of antitumor activity is atractylone, the EOs of CA, and the EOs of BA; the DEX, EOs of CA, EOs of $\mathrm{BA}$ and atractylone can significantly reduce the secretion of the NO content after stimulation, so it is believed that the EOs of CA, EOs of BA and atractylone have anti-inflammatory activity.

Author Contributions: B.W. and T.Z. contributed to the conception of the study; S.G. and L.L. contributed significantly to the analysis and manuscript preparation; H.H. performed the data analyses. All authors read and approved the manuscript.

Funding: This work was financially supported by National Natural Science Foundation of China (project No. 2017ZX09201010-014-014), Shanghai China Medicine Development Three-Year Action Plan (project No. ZY3-CCXX-3-4001), and Foundation of the Shanghai Science and Technology Commission (project No. 17401902300).

Acknowledgments: We are grateful to the constructive discussions from Haiyan Zhu of Teaching Center of Pharmaceutical Sciences, School of Pharmacy, Fudan University for technical support.

Conflicts of Interest: The authors declare there is no conflict of interest.

\section{References}

1. Hoang, L.S.; Tran, M.H.; Lee, J.S.; Ngo, Q.M.; Woo, M.H.; Min, B.S. Inflammatory inhibitory activity of sesquiterpenoids from Atractylodes macrocephala rhizomes. Chem. Pharm. Bull. (Tokyo) 2016, 64, 507-511. [CrossRef] [PubMed]

2. Cai, H.; Xu, Z.; Luo, S.; Zhang, W.; Cao, G.; Liu, X.; Lou, Y.; Ma, X.; Qin, K.; Cai, B. Study on chemical fingerprinting of crude and processed Atractylodes macrocephala from different locations in Zhejiang province by reversed-phase high-performance liquid chromatography coupled with hierarchical cluster analysis. Pharm. Mag. 2012, 8, 300-307. [CrossRef] [PubMed]

3. Yu, L.; Jia, T.; Qian, C. Rearch on the chemical references of Atractylodes macrocephala Koidz. Asia-Pac. Tradit. Med. 2010, 6, 36-39.

4. Liu, P.; Teng, J.; Zhang, Y.W.; Takaishi, Y.; Duan, H.Q. Chemical constituents from rhizome of Phlomis umbrosa. Yao Xue Xue Bao Acta Pharm. Sin. 2007, 42, 401-404.

5. Pharmacopoeia Commission of the Ministry of Health of the People's Republic of China. Pharmacopoeia of the People's Republic of China; China Medical Science Press: Beijing, China, 2015.

6. Wang, X.T.; Li, L.H.; Ran, X.K.; Dou, D.Q.; Li, B.; Yang, B.Y.; Li, W.; Koike, K.; Kuang, H.X. What caused the changes in the usage of Atractylodis macrocephalae Rhizoma from ancient to current times? J. Nat. Med. Tokyo 2016, 70, 36-44. [CrossRef] [PubMed]

7. Zhang, J.D.; Cao, G.; Xia, Y.H.; Wen, C.P.; Fan, Y.S. Fast analysis of principal volatile compounds in crude and processed Atractylodes macrocephala by an automated static headspace gas chromatography-mass spectrometry. Pharm. Mag. 2014, 10, 249-253. [CrossRef] [PubMed]

8. Ji, G.Q.; Chen, R.Q.; Wang, L. Anti-inflammatory activity of atractylenolide III through inhibition of nuclear factor-kappa B and mitogen-activated protein kinase pathways in mouse macrophages. Immunopharm. Immunot. 2016, 38, 98-102. [CrossRef] [PubMed]

9. Chen, J.; Liu, X.; Dou, D.Q. Bidirectional effective components of Atractylodis macrocephalae Rhizoma on gastrointestinal peristalsis. Int. J. Pharm. 2016, 12, 108-115. [CrossRef] 
10. Song, H.P.; Hou, X.Q.; Li, R.Y.; Yu, R.; Li, X.; Zhou, S.N.; Huang, H.Y.; Cai, X.; Zhou, C. Atractylenolide I stimulates intestinal epithelial repair through polyamine-mediated $\mathrm{Ca}^{2+}$ signaling pathway. Phytomedicine 2017, 28, 27-35. [CrossRef]

11. Huang, H.L.; Lin, T.W.; Huang, Y.L.; Huang, R.L. Induction of apoptosis and differentiation by atractylenolide-1 isolated from Atractylodes macrocephala in human leukemia cells. Bioorg. Med. Chem. Lett. 2016, 26, 1905-1909. [CrossRef]

12. Liu, H.Y.; Zhu, Y.J.; Zhang, T.; Zhao, Z.G.; Zhao, Y.; Cheng, P.; Li, H.; Gao, H.; Su, X.M. Anti-tumor effects of Atractylenolide I isolated from Atractylodes macrocephala in human lung carcinoma cell lines. Molecules 2013, 18, 13357-13368. [CrossRef] [PubMed]

13. Long, F.Y.; Wang, T.; Jia, P.; Wang, H.F.; Qing, Y.; Xiong, T.T.; He, M.J.; Wang, X.L. Anti-tumor effects of Atractylenolide-I on human ovarian cancer cells. Med. Sci. Monit. 2017, 23, 571-579. [CrossRef] [PubMed]

14. Zhou, J.R.; Yuan, X.R.; Li, L.; Zhang, T.; Wang, B. Comparison of different methods for extraction of Cinnamomi ramulus: Yield, chemical composition and in vitro antiviral activities. Nat. Prod. Res. 2017, 31, 2909-2913. [CrossRef] [PubMed]

15. Comelli, N.C.; Romero, O.E.; Diez, P.A.; Marinho, C.F.; Schliserman, P.; Carrizo, A.; Ortiz, E.V.; Duchowicz, P.R. QSAR study of biologically active essential oils against beetles infesting the walnut in Catamarca, Argentina. J. Agr. Food Chem. 2018, 66, 12855-12865. [CrossRef] [PubMed]

16. Perez-Outeiral, J.; Elcoroaristizabal, S.; Amigo, J.M.; Vidal, M. Development and validation of a method for the determination of regulated fragrance allergens by High-Performance Liquid Chromatography and parallel factor analysis 2. J. Chromatography A 2017, 1526, 82-92. [CrossRef] [PubMed]

17. Szoke, E.; Maday, E.; Kiss, S.A.; Sonnewend, L.; Lemberkovics, E. Effect of magnesium on essential oil formation of genetically transformed and non-transformed chamomile cultures. J. Am. Coll. Nutr. 2004, 23, 763s-767s. [CrossRef] [PubMed]

18. Jiang, T.; Li, K.F.; Liu, H.H.; Yang, L. Extraction of biomedical compounds from the wood of Pterocarpus macarocarpus Kurz heartwood. Pak. J. Pharm. Sci. 2018, 31, 913-918.

19. Li, X.F.; Mou, Z.; Wang, X.P.; Wu, H.M.; Xu, F.; Zhu, C.X.; Zhang, M. Geographic analysis of the cultivation region of Ai pian derived from Blumea balsamifera through the determination of volatiles in the medicinal product and blood of treated mice by gas chromatography-mass spectrometry (GC-MS). Instrum. Sci. Technol. 2019, 47, 597-610. [CrossRef]

20. Sedaghat Doost, A.; Stevens, C.V.; Claeys, M.; Van Der Meeren, P. Fundamental study on the salt tolerance of oregano essential oil-in-water nanoemulsions containing tween 80. Langmuir: ACS J. Surf. Colloids 2019. [CrossRef]

21. Zhang, X.; Li, M.; Cheng, Z.; Ma, L.; Zhao, L.; Li, J. A comparison of electronic nose and gas chromatography-mass spectrometry on discrimination and prediction of ochratoxin A content in Aspergillus carbonarius cultured grape-based medium. Food Chem. 2019, 297, 124850. [CrossRef]

22. El Mokni, R.; Majdoub, S.; Chaieb, I.; Jlassi, I.; Joshi, R.K.; Hammami, S. Chromatographic analysis, antimicrobial and insecticidal activities of the essential oil of Phlomis floccosa D. Don. Biomed. Chromatogr. BMC 2019. [CrossRef] [PubMed]

23. Chen, F.; Jia, J.; Zhang, Q.; Gu, H.; Yang, L. A modified approach for isolation of essential oil from fruit of Amorpha fruticosa Linn using microwave-assisted hydrodistillation concatenated liquid-liquid extraction. J. Chromatography A 2017, 1524, 254-265. [CrossRef] [PubMed]

24. Gong, F.; Zhang, Q.; Wang, B.T. Chemical characterization of herbal formula yupingfeng powder and its single herbs (i) volatile components. Anal. Lett. 2009, 42, 2610-2624. [CrossRef]

25. Andriana, Y.; Xuan, T.D.; Quy, T.N.; Tran, H.D.; Le, Q.T. Biological activities and chemical constituents of essential oils from Piper cubeba Bojer and Piper nigrum L. Molecules 2019, 24, 1876. [CrossRef] [PubMed]

26. Cao, G.; Cai, H.; Cong, X.; Liu, X.; Ma, X.; Lou, Y.; Qin, K.; Cai, B. Global detection and analysis of volatile components from sun-dried and sulfur-fumigated herbal medicine by comprehensive two-dimensional gas chromatography/time-of-flight mass spectrometry. Analyst 2012, 137, 3828-3835. [CrossRef] [PubMed] 
27. Karakaya, S.; Koca, M.; Yilmaz, S.V.; Yildirim, K.; Pinar, N.M.; Demirci, B.; Brestic, M.; Sytar, O. Molecular docking studies of coumarins isolated from extracts and essential oils of zosima absinthifolia link as potential inhibitors for Alzheimer's disease. Molecules 2019, 24, 722. [CrossRef] [PubMed]

28. Le, T.B.; Beaufay, C.; Nghiem, D.T.; Pham, T.A.; Mingeot-Leclercq, M.P.; Quetin-Leclercq, J. Evaluation of the anti-trypanosomal activity of vietnamese essential oils, with emphasis on curcuma longa L. and its components. Molecules 2019, 24, 1158. [CrossRef]

29. Stoev, G. Application and chiral recognition of heptakis (2,6-di-O-methyl-3-O-trifluoroacetyl)-beta-cyclodextrin as a stationary phase for the gas-chromatographic separation of enantiomers. J Chromatogr. 1992, 589, 257-263. [CrossRef]

30. Guo, F.Q.; Huang, L.F.; Zhou, S.Y.; Zhang, T.M.; Liang, Y.Z. Comparison of the volatile compounds of Atractylodes medicinal plants by headspace solid-phase microextraction-gas chromatography-mass spectrometry. Anal. Chim. Acta 2006, 570, 73-78. [CrossRef]

31. Kapetanos, C.; Karioti, A.; Bojovic, S.; Marin, P.; Veljic, M.; Skaltsa, H. Chemical and principal-component analyses of the essential oils of apioideae taxa (Apiaceae) from central Balkan. Chem. Biodivers. 2008, 5, 101-119. [CrossRef]

32. Borisov, R.S.; Esparza, C.; Goriainov, S.V.; Zaikin, V.G. Suitable in-situ derivatization of alcohols by reaction with basic amines in direct analysis in real time mass spectrometry. Talanta 2019, 200, 31-40. [CrossRef] [PubMed]

33. Liao, G.; Chen, H.M.; Shi, B.F. Synthesis of phthalic acid derivatives via Pd-catalyzed alkoxycarbonylation of aromatic C-H bonds with alkyl chloroformates. Chem. Commun. 2018, 54, 10859-10862. [CrossRef] [PubMed]

34. Hamad, Y.K.; Abobakr, Y.; Salem, M.Z.M.; Ali, H.M.; Al-Sarar, A.S.; Al-Zabib, A.A. Activity of plant extracts/essential oils against three plant pathogenic fungi and mosquito larvae: GC/MS analysis of bioactive compounds. Bioresources 2019, 14, 4489-4511. [CrossRef]

35. El-Gawad, A.A.; Elshamy, A.; El Gendy, A.E.; Gaara, A.; Assaeed, A. Volatiles profiling, allelopathic activity, and antioxidant potentiality of xanthium strumarium leaves essential oil from egypt: Evidence from chemometrics analysis. Molecules 2019, 24, 584. [CrossRef] [PubMed]

36. Lin, Y.; Wang, G.H.; Yuan, K. Extraction and GC-MS analysis of the volatile constituents of a tractylodes macrocephala. Asian J. Chem. 2011, 23, 551-555.

37. Zhou, Q.; Liu, S.; Liu, Y.; Song, H. Comparative analysis of volatiles of 15 brands of extra-virgin olive oils using solid-phase micro-extraction and solvent-assisted flavor evaporation. Molecules 2019, 24, 1512. [CrossRef] [PubMed]

38. He, X.W.; Zhang, L.T.; Chen, J.P.; Sui, J.L.; Yi, G.H.; Wu, J.Y.; Ma, Y.Z. Correlation between chemical composition and antifungal activity of clausena lansium essential oil against candida spp. Molecules 2019, 24, 1394. [CrossRef] [PubMed]

39. Andrade, M.A.; das Gracas Cardoso, M.; de Andrade, J.; Silva, L.F.; Teixeira, M.L.; Valerio Resende, J.M.; da Silva Figueiredo, A.C.; Barroso, J.G. Chemical composition and antioxidant activity of essential oils from cinnamodendron dinisii schwacke and siparuna guianensis aublet. Antioxidants 2013, 2, 384-397. [CrossRef] [PubMed]

40. Wang, B.; Ge, L.; Mo, J.G.; Su, L.; Li, Y.J.; Yang, K.D. Essential oils and ethanol extract from Camellia nitidissima and evaluation of their biological activity. J. Food Sci. Tech. Mys. 2018, 55, 5075-5081. [CrossRef]

41. Mahanta, B.P.; Sut, D.; Kemprai, P.; Paw, M.; Lal, M.; Haldar, S. A (1) H-NMR spectroscopic method for the analysis of thermolabile chemical markers from the essential oil of black turmeric (Curcuma caesia) rhizome: Application in post-harvest analysis. Phytochem. Anal. PCA 2019. [CrossRef]

42. Benedetto, C.; D’Auria, M.; Mecca, M.; Prasad, P.; Singh, P.; Singh, S.; Sinisgalli, C.; Milella, L. Chemical and biological evaluation of essential oil from Saussurea costus (Falc.) Lipsch. from Garhwal Himalaya collected at different harvesting periods. Nat. Prod. Res. 2019, 33, 2355-2358. [CrossRef] [PubMed]

43. Dai, C.X.; Huang, X.Y.; Lv, R.Q.; Zhang, Z.C.; Sun, J.; Aheto, J.H. Analysis of volatile compounds of Tremella aurantialba fermentation via electronic nose and HS-SPME-GC-MS. J. Food Saf. 2018, 38. [CrossRef]

44. Mirza, B.; Samiei, S.S.; Taherkhani, M.; Fathizadeh, M. Composition of the essential oils of Anthemis hyalina DC., Achillea nobilis L. and Cichorium intybus L. Three asteraceae herbs growing wild in Iran. Asian J. Chem. 2012, 24, 1151-1154. 
45. Ling, Y.; Wang, X.M.; Wang, C.N.; Xu, C.J.; Zhang, W.; Zhang, Y.H.; Zhang, Y.N. Hybrids from farnesylthiosalicylic acid and hydroxamic acid as dual ras-related signaling and histone deacetylase (hdac) inhibitors: Design, synthesis and biological evaluation. Chemmedchem 2015, 10, 971-976. [CrossRef] [PubMed]

46. Elmassry, M.M.; Kormod, L.; Labib, R.M.; Farag, M.A. Metabolome based volatiles mapping of roasted umbelliferous fruits aroma via HS-SPME GC/MS and peroxide levels analyses. J. Chromatogr. B 2018, 1099, 117-126. [CrossRef] [PubMed]

47. Zhang, L.; Yang, Z.; Huang, Z.; Zhao, M.; Li, P.; Zhou, W.; Zhang, K.; Zheng, X.; Lin, L.; Tang, J.; et al. Variation in essential oil and bioactive compounds of curcuma kwangsiensis collected from natural habitats. Chem. Biodivers. 2017, 14. [CrossRef]

48. Zhu, J.; Jia, R.F.; Lai, P.X. Chemical composition of the essential oil of chloranthus serratus from China. Chem. Nat. Compd. 2017, 53, 159-161. [CrossRef]

49. Xu, S.Z.; Qi, X.J.; Liu, Y.Q.; Liu, Y.H.; Lv, X.; Sun, J.Z.; Cai, Q. UPLC-MS/MS of Atractylenolide I, Atractylenolide II, Atractylenolide III, and Atractyloside A in rat plasma after oral administration of raw and wheat bran-processed atractylodis rhizoma. Molecules 2018, 23, 3234. [CrossRef]

50. Su, H.H.; Wang, W.D.; Bao, L.Z.; Wang, S.S.; Cao, X.F. Synthesis and evaluation of essential oil-derived beta-methoxyacrylate derivatives as high potential fungicides. Molecules 2017, 22, 763. [CrossRef]

51. Zeng, M.N.; Li, M.; Li, M.; Zhang, B.B.; Li, B.K.; Zhang, L.; Feng, W.S.; Zheng, X.K. 2-Phenylacetamide isolated from the seeds of lepidium apetalum and its estrogen-like effects in vitro and in vivo. Molecules 2018, 23, 2293. [CrossRef]

52. Guo, Z.B.; Liu, Z.Z.; Yue, H.F.; Wang, J.Y. Beta-elemene increases chemosensitivity to 5-fluorouracil through down-regulating microRNA-191 expression in colorectal carcinoma cells. J. Cell Biochem. 2018, 119, 7032-7039. [CrossRef] [PubMed]

53. Chen, J.C.; Wang, T.Y.; Xu, S.T.; Lin, A.J.; Yao, H.Q.; Xie, W.J.; Zhu, Z.Y.; Xu, J.Y. Novel hybrids of natural beta-elemene bearing isopropanolamine moieties: Synthesis, enhanced anticancer profile, and improved aqueous solubility. Fitoterapia 2017, 120, 117-125. [CrossRef] [PubMed]

54. Ding, W.; Ning, L.P.; Xiong, Y.; Shi, H.; Wang, T.S.; An, R.M. Essential oils extracted from Phoebe hui Cheng ex Yang: Chemical constituents, antitumor and antibacterial activities, and potential use as a species identifier. J. Wood Chem. Technol. 2017, 37, 201-210. [CrossRef]

55. Oliveira, A.P.; Franca, H.S.; Kuster, R.M.; Teixeira, L.A.; Rocha, L.M. Chemical composition and antibacterial activity of Brazilian propolis essential oil. J. Venom. Anim. Toxins 2010, 16, 121-130. [CrossRef]

56. Jaradat, N.; Al-Lahham, S.; Abualhasan, M.N.; Bakri, A.; Zaide, H.; Hammad, J.; Hussein, F.; Issa, L.; Mousa, A.; Speih, R. Chemical constituents, antioxidant, cyclooxygenase inhibitor, and cytotoxic activities of teucrium pruinosum boiss. essential oil. Biomed. Res. Int. 2018, 2018, 4034689. [CrossRef] [PubMed]

57. Kim, H.Y.; Nam, S.Y.; Hwang, S.Y.; Kim, H.M.; Jeong, H.J. Atractylone, an active constituent of KMP6, attenuates allergic inflammation on allergic rhinitis in vitro and in vivo models. Mol. Immunol. 2016, 78, 121-132. [CrossRef] [PubMed]

58. Landy, J.; Ronde, E.; English, N.; Clark, S.K.; Hart, A.L.; Knight, S.C.; Ciclitira, P.J.; Al-Hassi, H.O. Tight junctions in inflammatory bowel diseases and inflammatory bowel disease associated colorectal cancer. World J. Gastroenterol. 2016, 22, 3117-3126. [CrossRef]

59. Vivinus-Nebot, M.; Frin-Mathy, G.; Bzioueche, H.; Dainese, R.; Bernard, G.; Anty, R.; Filippi, J.; Saint-Paul, M.C.; Tulic, M.K.; Verhasselt, V.; et al. Functional bowel symptoms in quiescent inflammatory bowel diseases: Role of epithelial barrier disruption and low-grade inflammation. Gut 2014, 63, 744-752. [CrossRef]

60. Schulzke, J.D.; Ploeger, S.; Amasheh, M.; Fromm, A.; Zeissig, S.; Troeger, H.; Richter, J.; Bojarski, C.; Schumann, M.; Fromm, M. Epithelial tight junctions in intestinal inflammation. Ann. New York Acad. Sci. 2009, 1165, 294-300. [CrossRef]

61. Ying, S.; Qing, S.; Li, C.Y. The effect of gentian violet on virulent properties of candida albicans. Mycopathologia 2010, 169, 279-285. [CrossRef]

62. Amparo, T.R.; Seibert, J.B.; Mathias, F.A.S.; Vieira, J.F.P.; Soares, R.; Freitas, K.M.; Cabral, V.A.R.; Brandao, G.C.; Santos, O.; de Souza, G.H.B.; et al. Anti-inflammatory activity of Protium spruceanum (Benth.) Engler is associated to immunomodulation and enzymes inhibition. J. Ethnopharmacol. 2019, 241, 112024. [CrossRef] [PubMed] 
63. Green, L.C.; Wagner, D.A.; Glogowski, J.; Skipper, P.L.; Wishnok, J.S.; Tannenbaum, S.R. Analysis of nitrate, nitrite, and [15N]nitrate in biological fluids. Anal. Biochem. 1982, 126, 131-138. [CrossRef]

64. Zhao, Y.; Wei, C.; Chen, X.; Liu, J.; Yu, Q.; Liu, Y.; Liu, J. Drug delivery system based on near-infrared light-responsive molybdenum disulfide nanosheets controls the high-efficiency release of dexamethasone to inhibit inflammation and treat osteoarthritis. ACS Appl. Mater. Interf. 2019, 11, 11587-11601. [CrossRef] [PubMed]

Sample Availability: Samples of atractylone is available from the authors.

(C) 2019 by the authors. Licensee MDPI, Basel, Switzerland. This article is an open access article distributed under the terms and conditions of the Creative Commons Attribution (CC BY) license (http://creativecommons.org/licenses/by/4.0/). 